\title{
Regional-Scale Landslide Susceptibility Mapping Using Limited LiDAR-Based Landslide Inventories for Sisak-Moslavina County, Croatia
}

\author{
Iris Bostjančić *, Marina Filipović, Vlatko Gulam and Davor Pollak
}

Citation: Bostjančić, I.; Filipović, M.; Gulam, V.; Pollak, D. Regional-Scale Landslide Susceptibility Mapping Using Limited LiDAR-Based Landslide Inventories for Sisak-Moslavina County, Croatia. Sustainability 2021, 13, 4543. https://doi.org/10.3390/su13084543

Academic Editor: Zoran Nakić

Received: 30 March 2021

Accepted: 18 April 2021

Published: 19 April 2021

Publisher's Note: MDPI stays neutral with regard to jurisdictional claims in published maps and institutional affiliations.

Copyright: (c) 2021 by the authors. Licensee MDPI, Basel, Switzerland. This article is an open access article distributed under the terms and conditions of the Creative Commons Attribution (CC BY) license (https:// creativecommons.org/licenses/by/ $4.0 /)$.

\author{
Department of Hydrogeology and Engineering Geology, Croatian Geological Survey, Sachsova 2, \\ 10000 Zagreb, Croatia; marina.filipovic@hgi-cgs.hr (M.F.); vlatko.gulam@hgi-cgs.hr (V.G.); \\ davor.pollak@hgi-cgs.hr (D.P.) \\ * Correspondence: iris.bostjancic@hgi-cgs.hr
}

\begin{abstract}
In this paper, for the first time, a regional-scale 1:100,000 landslide-susceptibility map (LSM) is presented for Sisak-Moslavina County in Croatia. The spatial relationship between landslide occurrence and landslide predictive factors (engineering geological units, relief, roughness, and distance to streams) is assessed using the integration of a statistically based frequency ratio (FR) into the analytical hierarchy process (AHP). Due to the lack of landslide inventory for the county, LiDAR-based inventories are completed for an area of $132 \mathrm{~km}^{2}$. From 1238 landslides, 549 are chosen to calculate the LSM and 689 for its verification. Additionally, landslides digitized from available geological maps and reported via the web portal "Report a landslide" are used for verification. The county is classified into four susceptibility classes, covering $36 \%$ with very-high and high and $64 \%$ with moderate and low susceptibility zones. The presented approach, using limited LiDAR data and the extrapolation of the correlation results to the entire county, is encouraging for primary regional-level studies, justifying the cost-benefit ratio. Still, the positioning of LiDAR polygons prerequires a basic statistical analysis of predictive factors.
\end{abstract}

Keywords: landslide susceptibility; regional-scale; LiDAR; frequency ratio; AHP; Croatia

\section{Introduction}

Over the last few decades, we have witnessed frequent occurrences of natural hazards, among which landslides are no exception. This trend is expected to continue in the future, according to [1], due to increased urbanization, continued deforestation, and increased regional precipitation caused by changing climate patterns. Keeping in mind that climate changes undoubtedly affect the stability of natural and engineered slopes [2,3], it is necessary to emphasize the need for future landslide risk reduction. Since landslides have a great impact on humans, their property, and the environment [4], knowledge improvement and raising awareness among the wider public should be highlighted. Considering landslides, one way that helps land-use planners and policy-makers to achieve sustainable land management is terrain zonation according to slope stability through susceptibility, hazard, and risk assessment [5,6].

Landslide susceptibility maps (LSM) show the spatial probability of landslide occurrence $[7,8]$. In areas where the possibility of their occurrence exists, the production of LSMs is an important step to define the geoenvironmental characteristics of the area in the aspect of spatial planning. The zonation of terrain according to the degree of landslide susceptibility is the foundation of rational land-use management, with an emphasis on safe and planned construction.

The basic concept of landslide-susceptibility assessment includes the spatial distribution of prevalent geoenvironmental factors to determine areas prone to landsliding without temporal implications [9]. LSM divides the area of interest into zones of the same 
or similar degree of susceptibility, which are ranked in a certain number of classes, namely four or five, described by qualitative terms such as very high, high, moderate, low, and very low [8].

Different human activities require maps to provide diverse spatial information, from very general to more detailed and very detailed. All of these requirements can be met only by producing maps at different scales. Thus, LSMs are also made at different scales, the choice of which is primarily defined by the purpose of the map and the size of the study area [9]. At the same time, the chosen scale, together with the availability, quality, and accuracy of input data; resolution of zoning; and required outputs, defines the appropriate methodology to be used [10].

Regional-scale LSMs refer to a medium scale of 1:100,000 to 1:25,000 for an area of 1000 to $10,000 \mathrm{~km}^{2}$ [9]. Considering that the choice of an appropriate method for a regionalscale LSM is greatly influenced by the size of the study area, a knowledge-based qualitative approach has been commonly used [11]. Statistically based quantitative methods are often applied to smaller areas but are also used to derive LSMs at a regional scale [12]. Thereby, to enable the comparison of the results, two or more different approaches are often employed in research (e.g., [13-15]). Additionally, in recent years, to reduce subjectivity and increase the prediction capability, different methods are combined, and various integrations of bivariate methods with qualitative, multivariate, and machine learning methods are presented (e.g., [16-21]).

In this paper, for the first time, the LSM is presented at a county level for Croatia, covering the $4,466 \mathrm{~km}^{2}$ area within Sisak-Moslavina County. Sisak-Moslavina County is one of the three counties that have been investigated in terms of landslides through the project "Transnational advanced management of land use risk through landslide susceptibility maps design" (abbreviation: safEarth). The project was conducted from 2017 to 2019 under the Interreg IPA Cross-border Cooperation Programme Croatia-Bosnia and HerzegovinaMontenegro 2014-2020. During project implementation, aerial laser scanning (ALS) was performed for six pilot polygons with a total area of approximately $300 \mathrm{~km}^{2}$, resulting in high-resolution (HR) light detection and ranging (LiDAR) digital terrain models (DTM). Of these, three LiDAR polygons were located within Sisak-Moslavina County, enabling LiDAR-based landslide inventories for an area of $132.43 \mathrm{~km}^{2}$. Their spatial distribution presents the initial step towards susceptibility assessment [22].

Considering that complete inventories over large areas or regions are mostly rare, this paper aims to assess the performance of regional-scale landslide-susceptibility mapping using limited LiDAR-based landslide inventories. LiDAR polygons, in that sense, served as training areas that are considered to have representative geological and other landslideinfluential characteristics of the entire study area.

To assess landslide-susceptibility, commonly used methods are applied. Additionally, the bivariate statistical frequency ratio (FR) method is integrated into the knowledgebased analytical hierarchy process (AHP). The presented LSM plays an important role in identifying areas of great susceptibility and has a direct contribution on the improvement of the spatial planning system, crisis management, and environmental protection.

\section{Study Area}

Sisak-Moslavina County is located in the central part of Croatia (Figure 1) and is its third-largest county, with an area of approximately $4500 \mathrm{~km}^{2}$. According to the 2011 census, it is inhabited by 172,000 people and incorporates twelve municipalities and seven cities, the largest of which is Sisak, its political and administrative seat. Geographically, the county can be divided into three units: mountainous areas, hilly areas, and river terraces. The river terraces and flood plains of the Sava, Kupa, and Glina rivers, mostly between 90 and $250 \mathrm{~m}$ above sea level, are situated in the central part of the county. The plains are surrounded by hilly countryside from 200 to 450 m.a.s.l. (Banovina, Vukomeričke gorice, and Psunj) or mountains whose highest peaks are up to 600 m.a.s.l. (Zrinska Gora, Trgovska Gora, Petrova Gora, and Moslavačka Gora). This area belongs to the megageomorphological 
region of the Pannonian Basin, which is subdivided into the macrogeomorphological regions of the northwestern Croatian valley and Slavonian massive mountains [23].

In Sisak-Moslavina County, $6 \%$ of the area is settled, $30 \%$ of the area is agricultural land, $40 \%$ is forested [24], and more than $18 \%$ of the area is classified as other agricultural and forest areas [25]. From the pedological perspective, gley, pseudogley, eluvial-illuvial, and cambic soils are dominant in this region [26].

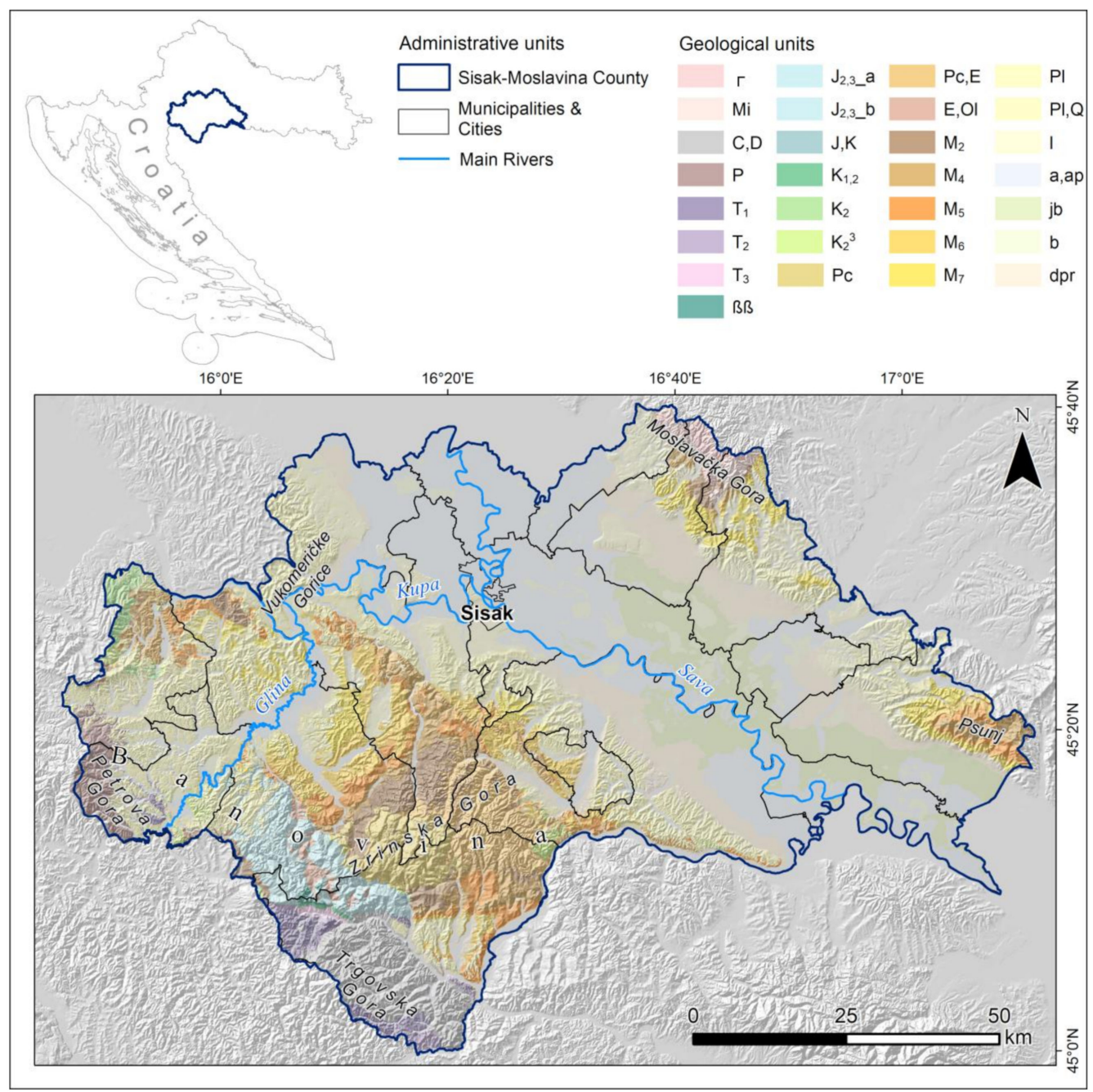

Figure 1. Location map of Sisak-Moslavina County with geological units based on 1:100,000 scale geological map [27].

\section{Geological Setting and Description of Geological Units}

The description of the geological units and development of the study area is mainly based on the BGM guidelines and the Mining-Geological Study of Sisak-Moslavina County [28]. As a part of the study, a 1:100,000-scale geological map of the county was produced [27], based on nine BGM sheets.

The oldest rocks, Paleozoic granites $(\Gamma)$, and various older metamorphic rocks (Mi), are found in the mountains of Moslavačka Gora and Papuk. Devonian and Carboniferous marine sediments in the Trgovska Gora Mountain are deposited in the flysch-turbiditic environment, represented by shales, sandstones, and limestone interlayers (C, D). Turbidite sedimentation continued during the Permian (P), forming interlayers of clays, siltites, and sandstones in lower horizons and gradually, coarser sediments like sandstones and conglomerates in the Late Permian (Petrova Gora Mountain).

Early Triassic shallow marine sediments (sandstones, siltites, shales, marls, and limestones- $\mathrm{T}_{1}$ ) are followed by deeper marine limestones, marls, cherts, and even py- 
roclastites $\left(\mathrm{T}_{2}\right)$. In the Late Triassic, a shallow marine environment dominated, producing dolomites $\left(\mathrm{T}_{3}\right)$. During the Middle and Late Jurassic, the spreading of the lithosphere in the Banija region caused uplifting of the ultramafic rocks and the formation of ophiolitic complexes. They are composed of various magmatic (diabase, spilites $-\beta \beta$ ), metamorphic (shales, phyllites, serpentinites, and amphibolites- $\mathrm{J}_{2,3} \mathrm{a}$ ), and sedimentary rocks (sandstones, shales, and cherts- $\mathrm{J}_{2,3} \mathrm{~b}$ ). Jurassic-Cretaceous clastites and pelagic limestones with rare intrusions of diabases and spilites $(\mathrm{J}, \mathrm{K})$ are also considered as a segment of the ophiolitic complex. During the Cretaceous, flysch sediments (sandstones, shales, and limestones- $\mathrm{K}_{1,2}$ ) are deposited, next to which submarine extrusions of diabases and spilites are recorded from the Late Cretaceous $\left(\mathrm{K}_{2}\right)$.

Flysch sediments were continuously deposited at the edge of the former Pannonian basin from the Late Cretaceous to the Paleogene. The structural characteristics of 100 to $150 \mathrm{~m}$ thick Senonian conglomerates, sandstones, and marls $\left(\mathrm{K}_{2}{ }^{3}\right)$ indicate the distal type of turbidite sequences [29]. Paleocene flysch ( $\mathrm{Pc})$ is dominantly characterized by sandstones, shales, and marls, with the thickness of the turbiditic sequences diminishing from approximately one to two $\mathrm{m}$ to several decimeters in distal zones [30]. Paleocene-Eocene flysch $(\mathrm{Pc}, \mathrm{E})$ is characterized by conglomerates, sandstones, and shales, rarely with marls and limestones, with an approximate thickness of $200 \mathrm{~m}$.

After a period of flysch sedimentation, the shallowing of the area is documented with freshwater sedimentation during the Eocene-Oligocene, when the river, lacustrine, and marsh sediments were deposited with local occurrences of coals (conglomerates, sandstones, marls, clays, and coal-E, Ol). The thickness of the whole series is 150 to $200 \mathrm{~m}$, with $50 \mathrm{~m}$ of brown coal that was experimentally exploited. During the Oligocene and Early Miocene, the North Croatian Basin is characterized by long emersion and strong tectonics, which formed new pre-Neogene relief [31]. In the Ottnangian, the terrain subsided, which enabled the deposition of gravels, sands, and clays with coals $\left(\mathrm{M}_{2}\right)$, of which the estimated thickness is 250 to $350 \mathrm{~m}$. The short terrigenous phase during the Karpatian was followed by marine transgression in the Early Badenian. Depending on preset terrain morphology, either freshwater, brackish or marine clastites, or evaporites and coals deposited $\left(\mathrm{M}_{4}\right)$. Firstly, at the base of the Badenian sequence, coarser clastic sediments deposited (conglomerates, gravels, and sandstones). The carbonate composite rises with the progress of marine transgression (up to $>90 \%$ ) during the Late Badenian, which enabled the deposition of reef limestones and, in the deeper sea, marls [32]. The thickness of Badenian sediments varies greatly, with a maximum of $300 \mathrm{~m}$.

A similar depositional environment continued during the Sarmatian $\left(\mathrm{M}_{5}\right)$. In coastal and shallow zones of the basin, coarser-grained clastics composed of polymictic conglomerates, gravels, sandstones, and sands were formed. Bioclastic limestones are characteristic of the shallow marine environment and of thinly plated marls with rare interbeds of turbiditic sands and sandstones deposited in deeper seas. The thickness of the Sarmatian deposits is, at maximum, $100 \mathrm{~m}$.

Sedimentation continued from the Sarmatian to the Pannonian, in a high-energy kaspibrackish environment with sands and sandy marls [29] or low energy shoreline with clayey limestones. The laminated and platy limestones with few-centimeter-thick beddings are very abundant (Croatica Fm.) in the Lower Pannonian. In the Middle Pannonian, laminated to thin-layered sands and sandy marls alternate with clayey limestones, and poorly lithified sandstones. During Late Pannonian subsidence, massive to weakly layered marls and sporadic clayey limestones and clays were deposited in the more distal part of the lacustrine basin (Medvedski breg Fm.; [33]). The thickness of the Pannonian deposits $\left(\mathrm{M}_{6}\right)$ is between 120 to $200 \mathrm{~m}$.

During the Pontian, the region was gradually uplifting with constant reduction of the sedimentation area. Clayey and silty marls deposited in the Early Pontian were gradually replaced by silts and sands in the Late Pontian $\left(\mathrm{M}_{7}\right)$ [29]. According to the latest lithostratigraphic nomenclature, Pontian deposits are subdivided into the Andraševec and Hum Zabočki Fm [34,35]. The Andraševec Fm is composed of the alternation of sands, silts, and 
marls [36] and is continuously overlain by the Hum Zabočki Fm, which is mostly composed of fine- to medium-grained sands, silty marls, clays, and coal seams. The thickness of the Pontian deposits varies between 150 to $450 \mathrm{~m}$.

After the Pontian, this region was tectonically uplifted, creating the protruded relief of the Trgovska and Petrova gora mountains. For the Pliocene, clays, sands, and gravels deposits (Pl) with a thickness of 200 to $400 \mathrm{~m}$ [37], associated with lacustrine and river environments, are characteristic. Pliocene sediments are equivalent to the Vrbova Fm. of the Sava basin $[33,38]$. During this time, the foresaid mountains became the main source of molasse gravels, sands, and clays that were deposited during the Plio-Quaternary. PlioQuaternary clastics (Pl, Q), with variable thickness in a range of 50 to $100 \mathrm{~m}$, unconformably cover various older deposits from the Jurassic to the Pontian ages [29,37]. Sands and gravels alternate, irregularly forming interlayers and lens-shaped bodies. Clays are deposited as centimeter- to decimeter-thick interlayers and lens-shaped bodies within the sands. Quaternary sediments occupy almost $50 \%$ of Sisak-Moslavina County. At the beginning of the Pleistocene, tectonic processes reactivated existing faults and river valleys were formed. That intensified erosion, and sedimentation started, mostly in the Sava but also other river valleys.

In the Early Pleistocene, aeolian clayey-sandy silts (loess-1) were deposited at the edges of Sava valley, with a thickness up to $30 \mathrm{~m}$.

During the Holocene, sedimentation was mostly related to river valleys and flatlands and is characterized by alluvial sands, gravels, silts, and clays (a, ap). The content and geometry of sediment bodies depend on facies: terrace, still water, flooded areas, and recent flows. Oxbow lake sediments form characteristically arched and elongated depressions, filled with mud, silt, and sand deposited during floods (jb). In the morphologically lowest parts of the Sava and Kupa River valleys, swamp areas are found. They mostly deposit dark clays and clayey silts (b) rich in organic matter [37], one to four m thick. Locally, the products of weathering, leaching, and torrential flows on slopes form poorly sorted and chaotic sediments on top of bedrock. Diluvial and proluvial sediments (dpr) are predominantly represented by sands and silts, with variable thickness that locally and rarely exceeds ten $\mathrm{m}$.

\section{Materials and Methods}

\subsection{Datasets}

One of the principal assumptions employed in statistically based susceptibility mapping is that future landslides will more likely occur under similar geological and geomorphological conditions which led to their activation in the past [39]. Thus, landslide occurrence can be determined by the evaluation of inventory against different conditioning factors to define their influence on landslide events $[40,41]$. It is crucial to have an accurate landslide inventory for the area studied, based on which suitable conditions for their activation can be defined. Spatial association analysis in this study is performed using LiDAR-based inventories and four environmental precondition factors. The landslide causative factors (triggers) that are more associated to hazard assessment were excluded from the analysis, as was the influence of anthropogenic activities.

\subsubsection{Landslide Inventories}

Within this paper, several landslide inventories are used. The inventories differ in data-collection methodology, the scale of the presentation, and the period in which data were collected (Table 1).

The HR LiDAR DTM with a $0.5 \mathrm{~m}$ resolution used in this study is derived from ALS conducted in the early spring of 2018 by a Slovenian company, Flycom Technologies d.o.o. Three LiDAR polygons covering an area of $132.43 \mathrm{~km}^{2}$ within Sisak-Moslavina County were processed. Landslide inventories were accomplished for wider areas of the City of Kutina $\left(68.20 \mathrm{~km}^{2}\right)$, City of Petrinja $\left(20.74 \mathrm{~km}^{2}\right)$, and the City of Glina and Dvor Municipality $\left(43.49 \mathrm{~km}^{2}\right)$. 
Table 1. Input data for different landslide inventories.

\begin{tabular}{|c|c|c|c|c|}
\hline Data & Characteristics & Collection Methodology & Date & Usage \\
\hline LiDAR-based DTM & $\begin{array}{l}0.5 \mathrm{~m} \text { resolution; } \\
\text { Croatian geological survey, } \\
\text { safEarth project }\end{array}$ & $\begin{array}{c}\text { Visual landslide recognition } \\
\text { using DTM } \\
\text { LiDAR derivatives }\end{array}$ & 2018 & $\begin{array}{l}\text { LSM calculation and } \\
\text { LSM verification }\end{array}$ \\
\hline $\begin{array}{c}\text { Engineering Geological } \\
\text { Map (EGM) [42] } \\
\text { Basic Geological }\end{array}$ & $\begin{array}{c}\text { 1:500,000; } \\
\text { Croatian geological survey }\end{array}$ & Synthesis from known data & 1967 & LSM verification \\
\hline $\begin{array}{l}\text { Map (BGM) * } \\
\text { Sheet Bosanski Novi [29]; } \\
\text { Sheet Kutina [43] }\end{array}$ & $\begin{array}{l}\text { 1:100,000; } \\
\text { Croatian geological survey }\end{array}$ & Field mapping & 2014 & $\begin{array}{l}\text { LSI classification and } \\
\text { LSM verification }\end{array}$ \\
\hline $\begin{array}{l}\text { Working field geological } \\
\text { maps (for BGM derivation) }\end{array}$ & $\begin{array}{l}\text { 1:25,000;Croatian } \\
\text { geological survey }\end{array}$ & Field mapping & Unknown & LSM verification \\
\hline $\begin{array}{l}\text { Web portal } \\
\text { "Report a landslide" }\end{array}$ & $\begin{array}{l}\text { Different spatial accuracy; } \\
\text { established by Croatian } \\
\text { geological survey }\end{array}$ & Reporting of landslides & 2018-present & LSM verification \\
\hline
\end{tabular}

* Only BGS sheets where landslides were drawn are listed in the Table.

The identification and delineation of landslide polygons is based on visual surface interpretation techniques (e.g., [22,44-46]). Thereby, HR DTM derivates (slope, contour lines, hillshade, and curvature) and orthophotos with a $10 \mathrm{~cm}$ resolution are analyzed using ArcGIS 10.2.1. During desktop landslide mapping, they were classified according to the landslide identification confidence (LIC), using scores from one to ten. LIC is presented as the degree of visibility; freshness; and the recognition of typical landslide features such as (i) main scarp, (ii) lateral flanks, (iii) toe, and (iv) internal morphology (e.g., minor scarps, internal cracks, hummocky, or rolling topography). All these features are soothed over time and are less recognizable in the field and on the digital elevation models (DEM) [47,48]. The LIC, in that sense, can serve as an indicator of relative landslide age. Thus, all landslides with LICs of one or two are considered inactive and old and are excluded from the analysis.

In total, 1238 landslide polygons with LIC higher than two are considered in the calculation, corresponding to an area of $2.25 \mathrm{~km}^{2}$ (1.7\% of the LiDAR polygons). The landslide area ranges from $6.88 \mathrm{~m}^{2}$ to $104,440.27 \mathrm{~m}^{2}$, with an average value of $1832.84 \mathrm{~m}^{2}$ (Table 2). It can be seen that the majority of polygons have low LIC values (3-6), indicating that active and younger landslides are still in the minority among the research polygons.

Table 2. Statistics of LiDAR-based landslide inventory.

\begin{tabular}{cccccc}
\hline \multirow{2}{*}{ LIC } & Count & \multicolumn{5}{c}{ Area $\left(\mathbf{m}^{\mathbf{2}}\right)$} \\
\cline { 3 - 6 } & & Sum & Average & Min & Max \\
\hline 3 & 423 & $712,467.45$ & 1684.32 & 41.30 & $30,783.49$ \\
4 & 266 & $461,175.47$ & 1733.74 & 6.88 & $104,440.27$ \\
5 & 239 & $509,236.50$ & 2130.70 & 118.94 & $51,673.51$ \\
6 & 138 & $292,361.59$ & 2118.56 & 94.33 & $20,632.18$ \\
7 & 77 & $126,368.64$ & 1641.15 & 105.74 & $10,682.77$ \\
8 & 60 & $83,125.78$ & 1385.43 & 42.55 & $7,422.04$ \\
9 & 23 & $34,799.25$ & 1513.01 & 137.86 & $4,837.63$ \\
10 & 12 & $29,469.42$ & 2455.78 & 255.33 & $7,507.53$ \\
\hline $3-10$ & 1238 & $2,249,004.10$ & 1832.84 & 6.88 & $104,440.27$ \\
\hline
\end{tabular}

Furthermore, a field prospection was performed, during which the depth of regolith and granulometric composition was estimated. A regolith is, according to the Dictionary of Earth Sciences [49], a layer of unconsolidated weathered material, including rock fragments, mineral grains, and all other superficial deposits, that rests on unaltered, solid bedrock. Field prospection discovered that mostly shallow and smaller landslides prevail in these terrains. 
A total of 549 landslide polygons, with an LIC greater than five, were used in statistical analysis to estimate susceptibility. The remaining 689 polygons with an LIC of three or four were used for the verification of the derived LSM.

In addition to LiDAR-based inventories, which are considered to be recent, historical inventories are digitized from available geological maps (Table 1). These landslides are presented as points, and their spatial distribution is given in Figure 2. In total, 152 landslides are mapped, 53 digitized from EGM, 34 digitized from BGMs, and 65 attributed to working field maps.

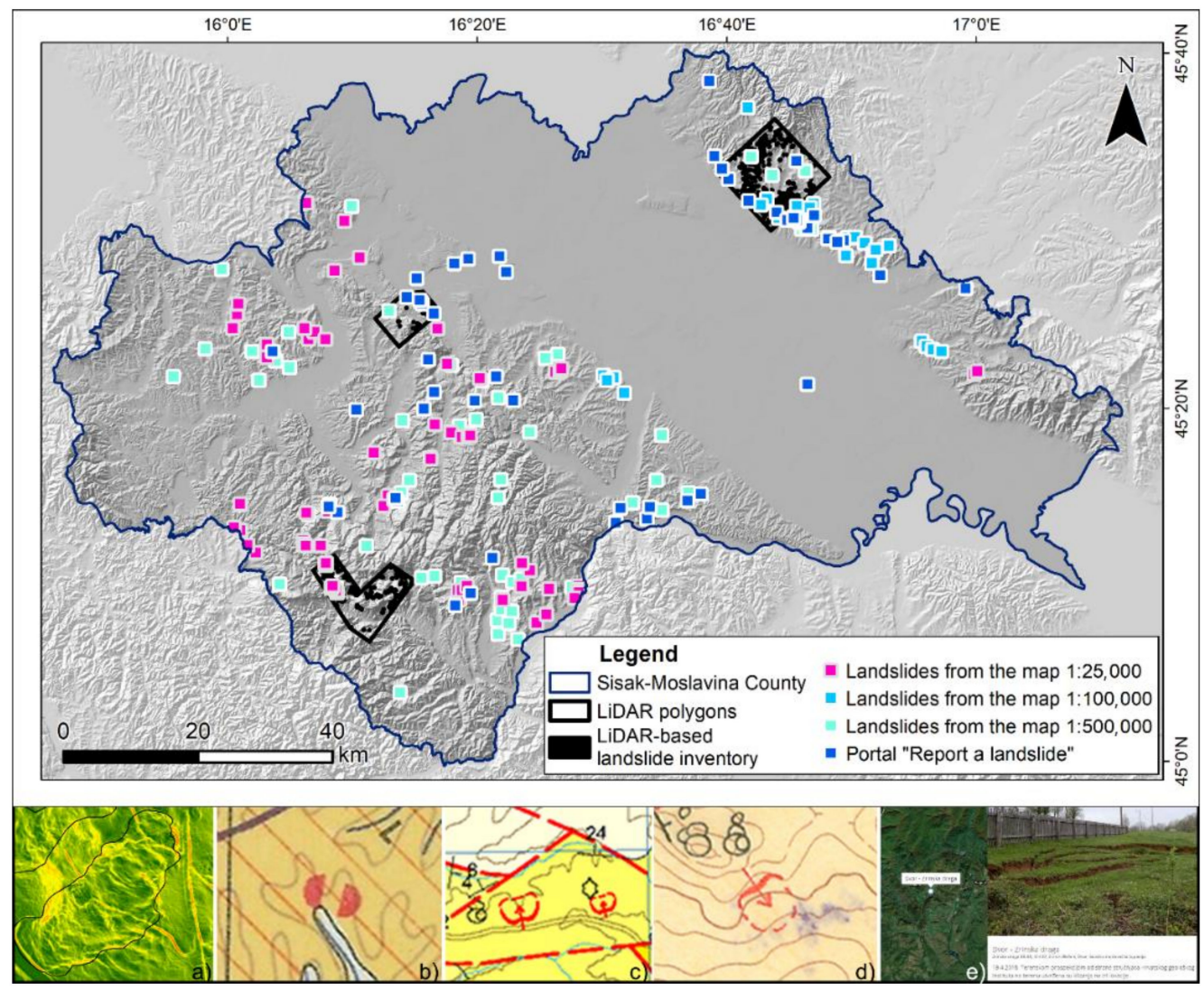

Figure 2. Landslide inventories with input data for their derivation: (a) visual landslide delineation using DTM LiDAR derivatives (e.g., slope), (b) landslides digitized from EGM 1:500,000, (c) landslides digitized from BGM 1:100,000, (d) landslides digitized from a field working geological map at 1:25,000, and (e) landslide reported via a web portal.

The last presented inventory is taken from the publicly available web portal "Report a landslide". This portal was established during safEarth project implementation in 2018 and is still active. Up to now, 57 landslides within Sisak-Moslavina County have been reported, mainly by the directorate of civil protection and local communities.

\subsubsection{Landslide Predictive Factors}

In the present study, four frequently used landslide predisposing factors were analyzed to map the susceptible areas: (i) engineering geological (EG) units, (ii) relief, (iii) roughness, and (iv) distance to streams, for all of which theoretical reasons exist that justify their use in susceptibility assessment [12]. The raster maps of all predictive factors were prepared in a GIS environment with a $20 \mathrm{~m}$ spatial resolution, based on the 1:100,000 scale geological map of Sisak-Moslavina County [27] for EG units and Croatian DEM with $20 \mathrm{~m}$ resolution for all other factor maps. 


\section{EG Units}

Due to the lack of 1:100,000-scale EG maps for Croatian territory, geological units established through the available geological map (presented in Section 2) were used to define the EG units. The reclassification is based on pure EG logic and experience gained during the field prospection. Therefore, the simplified EG rock classification is used (Table 3), according to which two main groups are determined: soil and rock. Regarding landslide occurrence, the main difference between these groups is in the position of the failure surface against the bedrock material.

Table 3. Simplified EG classification.

\begin{tabular}{|c|c|c|}
\hline Group & Subgroup & Class \\
\hline Soil & $\begin{array}{l}\text { Coherent } \\
\text { Mixture } \\
\text { Noncoherent }\end{array}$ & $\begin{array}{l}\text { Clay and silt } \\
\text { Clay, silt, sand, and gravel } \\
\text { Sand } \\
\text { Gravel }\end{array}$ \\
\hline Rock & Weak rocks & $\begin{array}{c}\text { Marls, siltstone, and shales } \\
\text { Clastic sedimentary rocks: sandstone, conglomerate, and breccia } \\
\text { Carbonate rocks } \\
\text { Igneous and metamorphic rocks }\end{array}$ \\
\hline
\end{tabular}

Landslides activated in the soil-group have deeper failure surfaces, which generally affect the parent soil material. Their activation is strongly influenced by the characteristics of the soil material. The homogeneity of soil material also has an impact on landslide characteristics and their occurrence. Thus, from the aspect of EG, it is very important to know if a particular geological unit consists of a homogeneous coherent material (e.g., mud and clay), a homogeneous noncoherent material (e.g., gravel and sand), or a heterogeneous mixture of those two. Accordingly, the soil-group is divided into three corresponding subgroups (Table 3 ).

Landslides activated in rock-groups have a shallow failure surface, which is usually positioned at the contact of the bedrock and the superficial material, the regolith. The failure surface, in weak rocks, can be situated in the bedrock, but these cases are rare and isolated in the study area. Landslide properties are primarily controlled by the characteristics of superficial material, which are not described within the BGM's guides. According to engineering experience, regolith characteristics (thickness, granulometric, and mineral composition) are primarily governed by the characteristics and/or type of the bedrock. Additionally, landslide activation can be strongly influenced by the impermeability of the bedrock, resulting in high pore pressure at the contact of the parent material and regolith.

The rock-group is divided into two subgroups, weak and durable rocks. Weak rocks, such as marls, siltstone, and shales, are very susceptible to weathering processes, the result of which is a thick (more than two $\mathrm{m}$ ) regolith, characterized mainly by a clayey-silt composition. Durable rocks are characterized by a thinner regolith with a much higher portion of a coarse-grained fraction. This subgroup includes classes of clastic sedimentary, carbonate, igneous, and metamorphic rocks.

Finally, for the study area, 29 geological units were reclassified into seven EG units (Table 4, Figure 3a).

Table 4. Reclassification of geological units.

\begin{tabular}{|c|c|c|}
\hline EG Unit & EG Unit/Complexes & Geological Unit \\
\hline 1 & Complex of coherent and noncoherent materials & dpr; jb; a, ap; Pl, Q; Pl; M2 \\
\hline 2 & Coherent materials & b; 1 \\
\hline 3 & Weak rocks & $\mathrm{M}_{5} ; \mathrm{M}_{6} ; \mathrm{M}_{7}$ \\
\hline 4 & Complex of durable rocks and weak rocks & $\mathrm{M}_{4} ; \mathrm{E}, \mathrm{Ol} ; \mathrm{Pc}, \mathrm{E} ; \mathrm{Pc}_{2} \mathrm{~K}_{2}^{3} ; \mathrm{T}_{1}$ \\
\hline 5 & Durable rocks: clastic sedimentary rocks & $\mathrm{K}_{2} ; \mathrm{K}_{1,2} ; \mathrm{J}, \mathrm{K} ; \mathrm{J}_{2,3} \mathrm{~b}^{\prime}$ \\
\hline 6 & Durable rocks: carbonate rocks & $\mathrm{T}_{3} ; \mathrm{T}_{2}$ \\
\hline 7 & Durable rocks: igneous and durable metamorphic rocks & $\mathrm{BB} ; \mathrm{J}_{2,3} \mathrm{a} ; \mathrm{P} ; \mathrm{C}, \mathrm{D} ; \Gamma ; \mathrm{Mi}$ \\
\hline
\end{tabular}




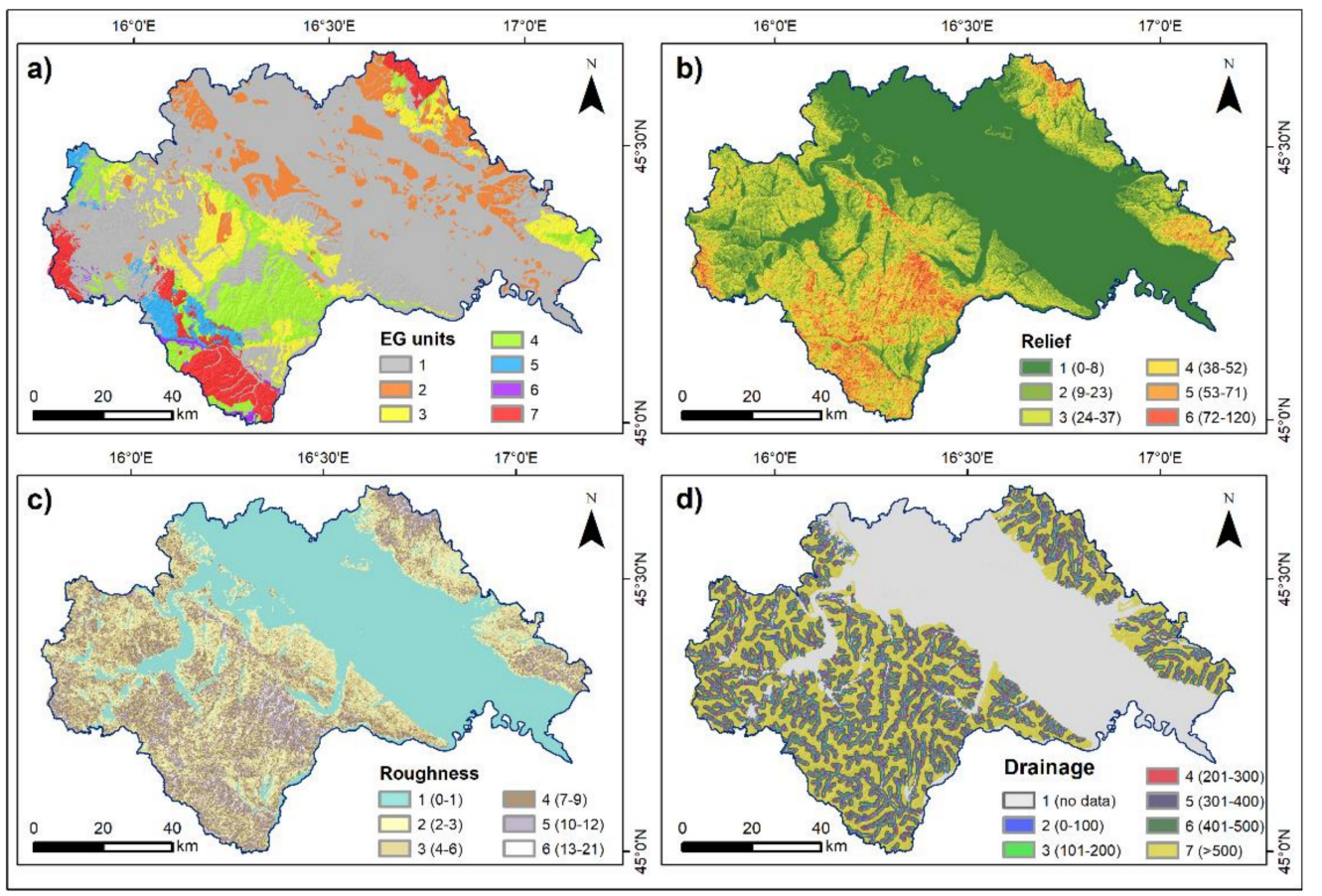

Figure 3. Reclassified predictive factor maps: (a) EG units, (b) relief, (c) roughness, and (d) distance to streams.

Relief

The relief represents a local altitude difference between the highest and lowest height within the unit area and gives an indication of the potential energy for soil erosion and landsliding [50]. In areas with higher relief, higher runoff and lower infiltration are expected [51]. The relief map is computed from the DEM using focal statistics, calculating the elevation range for the circle area with a radius of five cells around each cell. Calculated values are classified based on the natural breaks (Jenks) algorithm into six classes (Figure 3b): 1 (0-8 m), 2 (9-23 m), 3 (24-37 m), 4 (38-52 m), 5 (53-71 m), and 6 (72-120 m).

\section{Roughness}

Parameters correlated to surface roughness are quite commonly used to describe landslide activity in quantitative geomorphology [52]. Roughness is calculated from the slope map, which is derived directly from the DEM. The standard deviation of the slope is applied as one of the methods that have been used for studies at different scales [53]. Surface roughness was calculated using focal statistics. The radius taken around each cell to calculate the standard deviation was set to five cells. A $100 \mathrm{~m}$ window was chosen according to the DEM resolution and landslide dimensions. Roughness is classified based on the natural breaks (Jenks) algorithm into six classes (Figure 3c): $1\left(0-1^{\circ}\right), 2\left(2-3^{\circ}\right)$, $3\left(4-6^{\circ}\right), 4\left(7-9^{\circ}\right), 5\left(10-12^{\circ}\right)$, and $6\left(13-21^{\circ}\right)$.

\section{Distance to Streams}

Distance to streams is also one of the common conditioning factors used in landslidesusceptibility assessment [12]. Streams may negatively affect slope stability by eroding the toe of the slope or saturating the slope, which consequently leads to landsliding [54]. The stream network was automatically extracted from the DEM using Arc Hydro Tools v2.0. The derived drainage network was visually crosschecked on a Croatian topographic map at a scale of 1:25,000. Additionally, some minor rivers were manually extracted from the topographic map and major watercourses were removed, in order to retain lowerorder streams for the calculation; these are designated as headwater streams and medium streams [55]. The six buffer zones around these streams are defined for factor classification 
(Figure 3d), and the remaining areas are labeled as "no data", to which the smallest final weight is associated. Thus, seven classes are defined as follows: 1 (no data), 2 (0-100 m), 3 (101-200 m), 4 (201-300 m), 5 (301-400 m), 6 (401-500 m), and 7 (> $500 \mathrm{~m})$.

\subsection{Analytical Methods}

To derivate the LSM for Sisak-Moslavina County, the bivariate statistical FR method and its integration in the AHP is used, following several steps: (i) weighting the classes within each predictive factor; (ii) weighting each predictive factor; (iii) calculating the landslide susceptibility index (LSI), (iv) reclassifying the LSI values, and (v) verifying the LSM.

FR is based on the relationship between the spatial distribution of landslides and various classes of predictive factors [56]. The FR of each factor class is calculated separately for each predictive factor using Equation (1).

$$
F R=\frac{A_{L i} / A_{i}}{A_{L T} / A_{T}}
$$

where $A_{L i}$ is the area of landslides in the $\mathrm{i}$-th factor class, $A_{i}$ is the area of the $\mathrm{i}$-th factor class, $A_{L T}$ is the total area of landslides, and $A_{T}$ is the total area studied.

To enable the comparability between the $F R$ of different predictive factors, FR values are normalized $(F R n)$ into a range from zero to one using unity-based normalization, according to Equation (2).

$$
F R n=\left[F R-F R_{\text {min }}\right] /\left[F R_{\max }-F R_{\text {min }}\right]
$$

where $F R n$ represents normalized $F R$ value, $F R$ is the calculated value before normalization, and $F R_{\min }$ and $F R_{\max }$ are the minimum and maximum $F R$ values of classes within the corresponding predictive factor.

Besides the different impacts of factor classes, the influence of individual factors on landslide occurrence is also defined. To quantify the impact of each factor, the AHP method was used [57], of which the basic principle is to construct a comparison matrix expressing the relative importance of a set of attributes. Using the procedure described by [58] and [41], first, the predictor rate $(P R)$ was determined for each predictive factor based on the degree of spatial association with landslides expressed through FR values (Equation (3)), instead of subjectively expressed by expert knowledge.

$$
P R=\left[F R_{\text {max }}-F R_{\text {min }}\right] /\left[F R_{\text {max }}-F R_{\text {min }}\right]_{\text {min }}
$$

where the numerator represents the absolute difference between the maximum and minimum FR within each factor and the denominator represents the lowest absolute difference of all factors.

Second, a comparison matrix is obtained, showing the relative importance of each predictive factor, and used for the estimation of eigenvectors by normalizing the pairwise results for each column. Third, fractional weights (FW) are calculated by averaging the eigenvectors, performed by dividing the eigenvectors' row sum by the number of input predictive factors. Last, the FWs were converted into integer weights (IW) by dividing each of the FWs by the smallest FW of all factors and multiplying with the number 10 . The final factor class weights (FW) combine the factor classes' weights and factors' weights and are calculated by multiplying the normalized FR values (FRn) and IW values. Using the ArcGIS tool Raster calculator, the final weights of all overlapped factor maps are summed up to derive the LSI.

In order to present the studied area with zones of similar susceptibility to landslide occurrence, the LSI is reclassified into four classes based on its relationship with the cumulative number of landslides digitized from geological maps.

The verification of the LSM was performed using three different landslide datasets: (i) LiDAR-based landslide polygons with LICs of three or four, (ii) landslides digitized 
from different geological maps, and (iii) landslide locations collected via the web portal "Report a landslide". Landslide-susceptibility zones were verified with relative landslide density (RLD), calculated as a ratio between the landslide area or landslide number within each susceptibility zone and the area of corresponding susceptibility zone, all expressed in percentages.

\section{Results and Discussion}

\subsection{The Weighting of Predictive Factors}

Using the aforementioned approach, the first results for the LSM at a regional scale for Sisak-Moslavina County are presented. The results of the FR method, used to rank quantitatively the classes of each predictive factor to landslide susceptibility, are presented in Table 5. Factor classes that create the most favorable preconditions for landslide processes are identified as those with FR values greater than 1. Considering the EG units, landslides are mainly concentrated within EG unit 1, where $42 \%$ of landslide area is present. It can be considered to be the most critical landslide-prone unit, based on having the highest FR value of 1.75. A significant portion of landslide area is placed within EG units 4 and 5, comprising 16 and $13 \%$ of the landslide area, respectively. For those two units, FR values are greater than one. Although quite a bit of the landslide area, $18 \%$, is associated with EG unit 3, due to the relatively large area of this unit, the FR is below one. Within relief, classes 3 and 4 have the highest FR values, of 1.79 and 1.35, respectively. Within these units, $79 \%$ of the landslide area is present. The FR value for class 5 is close to $1(0.95)$, and this class contains $14 \%$ of the landslide area. Observing the FR results regarding roughness, classes 3 and 4 stand out with the highest FR values, of $1.39 \%$ and $1.17 .67 \%$ of the landslide area is placed within those classes. Analyzing the distance to streams, it is shown that FR values enlarge as distance increases. Thus, the highest FR, 1.54, is related to class 7 , within which $60 \%$ of the landslide area is present.

Integrating the FR weights in the AHP, the prediction rate (PR) and a pairwise comparison matrix of factors' relative importance to landslide susceptibility are determined (Table 6). Fractional weights (FW) and integer weights (IW), calculated over the estimated eigenvectors, are presented in Table 7. IWs are also expressed in percentages to get a better overview of factors' contribution to landslide susceptibility. Therefore, the influential role of EG units, relief, roughness, and distance to streams in landslide-susceptibility is expressed as $27 \%, 31 \%, 21 \%$, and $20 \%$, respectively (Table 7 ).

\subsection{Landslide Susceptibility Map and Verification}

Combining the normalized FR and IW, the final weights of each factor class are determined (Table 5) and used to calculate the LSI. The calculated LSI values vary within a range of 0 to 47 (Figures 4 and 5a), wherein higher values indicate greater susceptibility to landslide occurrence and vice versa. The derived map in its original form presents the LSI distribution over the study area (Figure 5a) with a cell size of $20 \times 20 \mathrm{~m}$. It is the resolution of all factor maps overlapped. The generated LSM is in the final step adjusted for regional scale (Figure 5b) by: (i) classifying the LSI, (ii) averaging the LSI, and (iii) resizing the cell size to $50 \times 50 \mathrm{~m}$.

To describe the different levels of landslide susceptibility, LSI values were classified into four susceptibility classes: low, moderate, high, and very high. Within this study, classification is based on the relation between LSI values and the percentage of the cumulative number of landslides, considering 152 landslide locations digitized from geological maps. Low and moderate classes are defined as areas where a maximum of $20 \%$ of cumulative landslides are present, and high and very high classes are defined as areas where at least $20 \%$ of cumulative landslides are present. The other two threshold values are set at 5 and $55 \%$ of the cumulative number of landslides. Based on those criteria, threshold LSI values were interpreted as 20, 26, and 32 (Figure 4).

The LSM is adjusted to a suitable scale of $1: 100,000$, at which the raster can be reliably used, by averaging the LSI value within each $100 \mathrm{~m}$ circle neighborhood with the mean 
statistic and setting the cell size to $50 \times 50 \mathrm{~m}$, according to the mathematical relationship between the map scale and the image resolution [59].

The representation of each landslide-susceptibility zone in Sisak-Moslavina County is shown in Table 8 . According to the results, very high and high landslide-susceptibility zones cover $36 \%$ of the county area, while moderate and low susceptibility zones cover $64 \%$.

Table 5. Results of frequency ratio (FR) with resulting integer weights (IW) and final weights (FW) presented.

\begin{tabular}{|c|c|c|c|c|c|c|}
\hline Class & $A_{\mathrm{Li}}\left(\mathrm{km}^{2}\right) *$ & $A_{i}\left(\mathbf{k m}^{2}\right) * *$ & FR & FRn (a) & IW (b) & $\mathbf{F W}(\mathbf{a} * \mathbf{b})$ \\
\hline \multicolumn{7}{|c|}{ EG unit } \\
\hline 1 & 0.46 & 32.03 & 1.75 & 1.00 & \multirow[t]{7}{*}{13} & 13.00 \\
\hline 2 & 0.02 & 12.35 & 0.21 & 0.00 & & 0.00 \\
\hline 3 & 0.20 & 32.83 & 0.74 & 0.34 & & 4.47 \\
\hline 4 & 0.17 & 17.80 & 1.19 & 0.64 & & 8.30 \\
\hline 5 & 0.14 & 14.06 & 1.25 & 0.68 & & 8.80 \\
\hline 6 & 0.01 & 2.32 & 0.43 & 0.14 & & 1.87 \\
\hline 7 & 0.08 & 21.04 & 0.46 & 0.16 & & 2.07 \\
\hline \multicolumn{7}{|l|}{ Relief } \\
\hline 1 & 0.00 & 7.03 & 0.01 & 0.00 & \multirow[t]{6}{*}{15} & 0.00 \\
\hline 2 & 0.06 & 28.03 & 0.25 & 0.14 & & 2.04 \\
\hline 3 & 0.43 & 38.93 & 1.35 & 0.75 & & 11.23 \\
\hline 4 & 0.42 & 29.00 & 1.79 & 1.00 & & 15.00 \\
\hline 5 & 0.15 & 18.96 & 0.95 & 0.53 & & 7.89 \\
\hline 6 & 0.02 & 10.47 & 0.29 & 0.16 & & 2.34 \\
\hline \multicolumn{7}{|c|}{ Roughness } \\
\hline 1 & 0.01 & 6.07 & 0.17 & 0.00 & \multirow[t]{6}{*}{11} & 0.00 \\
\hline 2 & 0.23 & 34.98 & 0.82 & 0.53 & & 5.87 \\
\hline 3 & 0.40 & 42.01 & 1.17 & 0.82 & & 9.03 \\
\hline 4 & 0.32 & 28.27 & 1.39 & 1.00 & & 11.00 \\
\hline 5 & 0.10 & 15.88 & 0.79 & 0.51 & & 5.59 \\
\hline 6 & 0.01 & 5.21 & 0.28 & 0.09 & & 0.98 \\
\hline \multicolumn{7}{|c|}{ Distance to streams } \\
\hline 1 & - & - & - & - & \multirow[t]{7}{*}{10} & 0.00 \\
\hline 2 & 0.05 & 17.02 & 0.39 & 0.00 & & 0.00 \\
\hline 3 & 0.07 & 16.74 & 0.53 & 0.12 & & 1.21 \\
\hline 4 & 0.09 & 16.56 & 0.68 & 0.26 & & 2.56 \\
\hline 5 & 0.09 & 15.15 & 0.76 & 0.32 & & 3.21 \\
\hline 6 & 0.11 & 13.85 & 0.98 & 0.51 & & 5.11 \\
\hline 7 & 0.65 & 50.94 & 1.54 & 1.00 & & 10.00 \\
\hline
\end{tabular}

* $\mathrm{A}_{\mathrm{Li}}$ is the area of landslides in the $\mathrm{i}$-th class of the factor; the total landslide area is $1.08 \mathrm{~km}^{2}$. ${ }^{* *} \mathrm{~A}_{\mathrm{i}}$ is the area of the $\mathrm{i}$-th factor class; the total study area is $132.43 \mathrm{~km}^{2}$.

Table 6. Prediction rate (PR) and pairwise comparison matrix.

\begin{tabular}{ccccccc}
\hline Factor & PR & & (1) & (2) & (3) & (4) \\
\hline EG unit (1) & 1.34 & $(1)$ & 1.00 & 0.86 & 1.26 & 1.34 \\
Relief (2) & 1.55 & $(2)$ & 1.16 & 1.00 & 1.46 & 1.55 \\
Roughness (3) & 1.06 & $(3)$ & 0.79 & 0.68 & 1.00 & 1.06 \\
Distance to streams (4) & 1.00 & $(4)$ & 0.75 & 0.65 & 0.94 & 1.00 \\
\hline
\end{tabular}

Table 7. Estimated eigenvectors of the pairwise comparison matrix, with fractional weights (FW) and integer weights (IW).

\begin{tabular}{ccccccccc}
\hline & $\mathbf{( 1 )}$ & $\mathbf{( 2 )}$ & $\mathbf{( 3 )}$ & $\mathbf{( 4 )}$ & Sum & FW & IW & IW (\%) \\
\hline$(1)$ & 0.27 & 0.27 & 0.27 & 0.27 & 1.08 & 0.27 & 13 & 27 \\
$(2)$ & 0.31 & 0.31 & 0.31 & 0.31 & 1.25 & 0.31 & 15 & 31 \\
$(3)$ & 0.21 & 0.21 & 0.21 & 0.21 & 0.86 & 0.21 & 11 & 21 \\
$(4)$ & 0.20 & 0.20 & 0.20 & 0.20 & 0.81 & 0.20 & 10 & 20 \\
Sum & 1.00 & 1.00 & 1.00 & 1.00 & & & & 100 \\
\hline
\end{tabular}




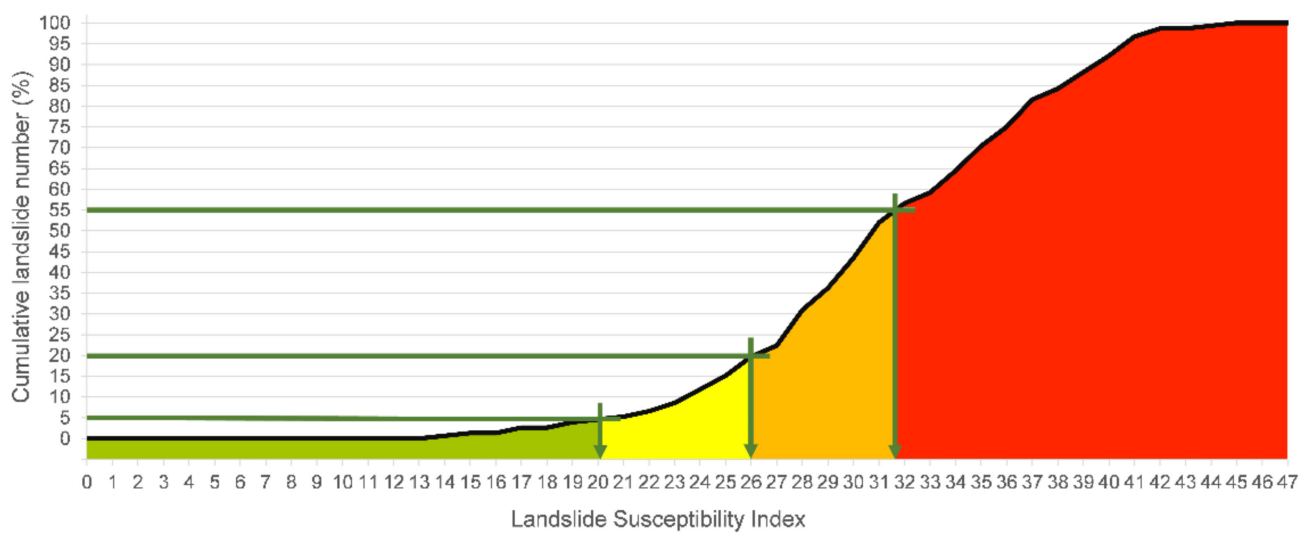

Figure 4. Reclassification of landslide susceptibility index (LSI).
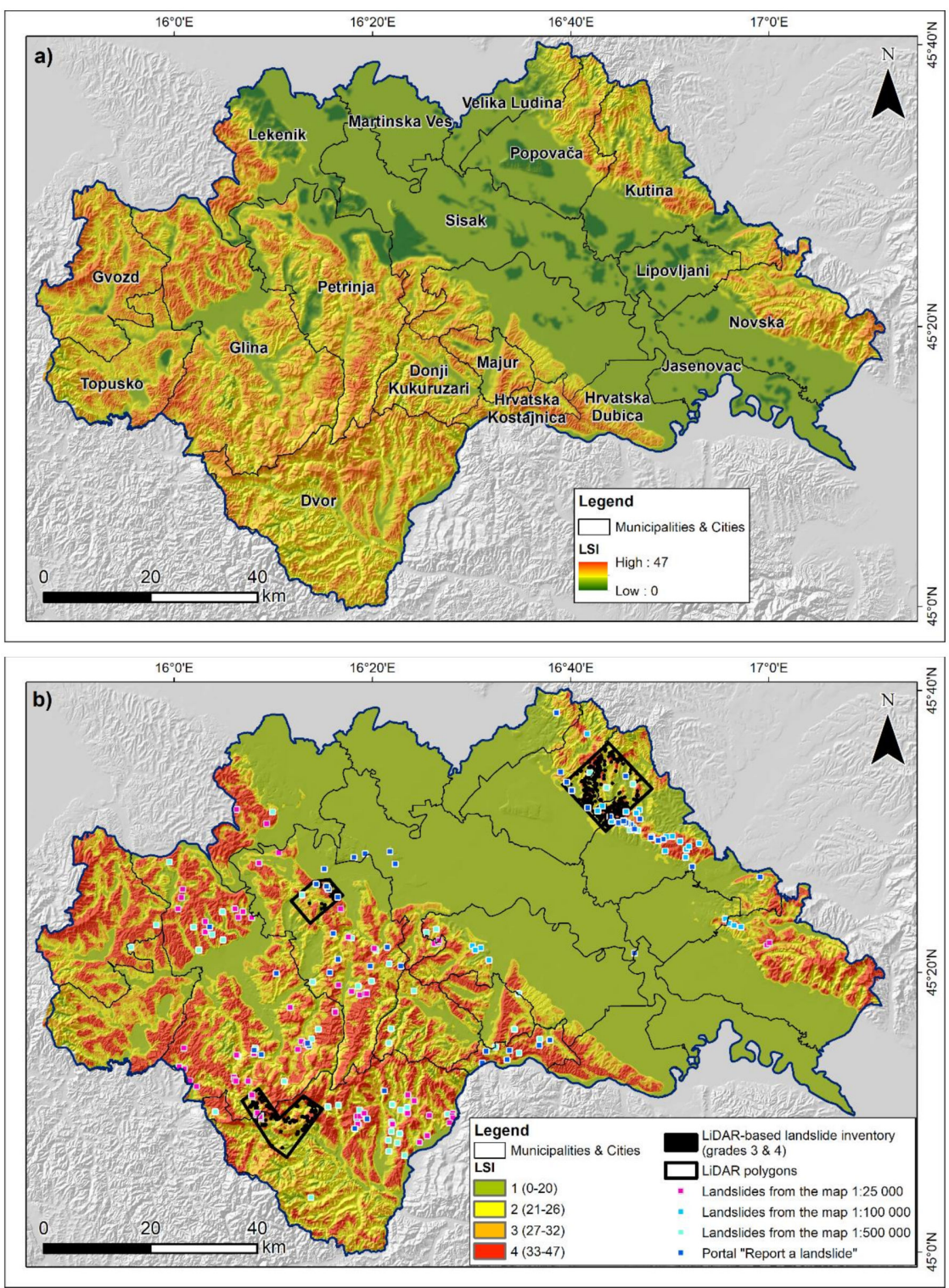

Figure 5. Generated landslide-susceptibility map: (a) in the original form derived by direct factor maps overlapping and summing their final weights (cell size: $20 \times 20 \mathrm{~m}$ ), and (b) in the form adjusted to regional scale with LSI classification and performed focal statistics (cell size: $50 \times 50 \mathrm{~m}$ ). 
Table 8. Areas of landslide-susceptibility class and relative landslide density within each class.

\begin{tabular}{cccccccccc}
\hline \multirow{2}{*}{$\begin{array}{c}\text { Landslide } \\
\begin{array}{c}\text { Susceptibility } \\
\text { Zone }\end{array}\end{array}$} & \multirow{2}{*}{ Area (\%) } & \multicolumn{2}{c}{ 1st Set } & \multicolumn{2}{c}{ 2nd Set } & \multicolumn{2}{c}{ 3rd Set } & 4th Set \\
\cline { 3 - 8 } & & Number (\%) & RLD1 & Area (\%) & RLD2 & Number (\%) & RLD3 & Area (\%) & RLD4 \\
\hline Low (1) & 50 & 5 & 0.09 & 1 & 0.02 & 16 & 0.32 & 1 \\
Moderate (2) & 14 & 15 & 1.06 & 15 & 1.07 & 14 & 0.99 & 11 & 0.77 \\
\hline$(1)+(2)$ & 64 & 20 & 0.31 & 16 & 0.25 & 30 & 0.47 & 12 & 0.19 \\
\hline High (3) & 17 & 37 & 2.11 & 36 & 2.07 & 23 & 1.31 & 27 & 1.56 \\
Very high (4) & 19 & 43 & 2.33 & 48 & 2.57 & 47 & 2.54 & 61 & 3.26 \\
\hline (3)+(4) & 36 & 80 & 2.22 & 84 & 2.33 & 70 & 1.94 & 88 & 2.44 \\
\hline
\end{tabular}

1st set-landslides digitized from maps; 2nd set-LiDAR-based landslide polygons (3,4); 3rd set-web portal "Report a landslide"; 4th set-LiDAR-based landslide polygons $(>5)$.

LSM is verified using three landslide datasets, as presented in Table 8 , in order to ascertain their reliability for the intended purpose. The overall verification results show that, for all verification sets, at least $70 \%$ of the landslide locations (points or areas) match the most susceptible zones, i.e., areas of very-high and high susceptibility. Furthermore, at most, $30 \%$ of the landslide locations (points or areas) match least susceptible zones, i.e., areas of moderate and low susceptibility. Among verification datasets, the results obtained for the first and second set are very similar and demonstrate the stronger spatial relationship between landslide locations and zones of higher susceptibility when compared to the third set.

The RLD indicates the general quality of the LSM [18]. Considering all three verification datasets, it is evident that the RLD slightly increases, moving from the lowest to the highest susceptibility class (Table 8). The RLD within the low susceptibility zone is below 0.1 for the first and second verification set, and below 0.32 for the third set. Further, the RLD increases up to a maximum of 2.33 within a very high susceptibility class for the second verification set. Overall, it can be concluded that the RLD within both low and moderate susceptibility zones is below 0.5 , and that within the high and very-high susceptibility zones, it is around two. For comparison, the fourth set is added, which relates to the LiDAR-based landslide polygons with an LIC greater than five. There, the RLD ranges from 0.02 (low susceptibility zone) to 3.26 (very high susceptibility zone).

\subsection{Limitations}

LSM techniques have evolved greatly over the last few decades and numerous techniques have been proposed and applied by many researchers. Although the performance of some methods has been proven to be better than others, there is no single method superior in all environments, and each technique has its unique advantages and limitations $[12,60]$. Therefore, optimal susceptibility zonation by combining several methods is recommended [12,61]. In this study, the integration of FR into AHP is used, to avoid subjectivity in defining the relative importance of predictive factors.

A well-known constraint during the derivation of LSM for larger regions is the relative scarcity of available data, relating to both the landslide inventory and predictive factor maps. To overcome the limitation of the nonexistence of a complete inventory for the entire county, limited LiDAR polygons are used to produce landslide inventories. The polygons are carefully selected to incorporate not only known landslide-susceptible geological units, but also other units and environments for which the landsliding potential is not known. LiDAR polygons represent the testing area where the spatial correlation between landslide occurrence and predictive factors was estimated. Correlation results are extrapolated to the entire county. The biggest limitation during the LSM model development was related to the size of the area covered with LiDAR polygons, which is, in the present study, limited to approximately three percent of the county area. The results of weighting factors used to define the LSI are strongly influenced by the representation of all predictive factor classes within LiDAR polygons. It is concluded that, for such large areas and regions, the positioning of LiDAR polygons prerequires a basic statistical analysis of predictive factors. 
If LiDAR polygons do not cover all the classes of predictive factors proportionally, further ALS should be directed and/or redistributed to capture the missing data.

The proportions of each class of predictive factors within LiDAR polygons are presented in Figure 6. It is shown that the area of EG units within LiDAR polygons is not equally distributed (Figure 6a). Still, EG unit 1, which is, from engineering geological experience, known as susceptible to landsliding, has the largest FR, although only $1.18 \%$ of this unit is covered with LiDAR polygons. The classes for other predictive factors are evenly covered with LiDAR polygons, except for the first classes (Figure $6 \mathrm{~b}-\mathrm{d}$ ). Those classes are related to lowland areas (Sava and Kupa valleys) and gentle slopes within the county where landslides are not so frequent. Thus, those areas were not considered to be priorities and were not in focus during the first ALS scanning of this region. Our future investigations will be focused on covering at least five percent (red line on the graphs in Figure 6, right vertical axis) of each class with HR LiDAR data.

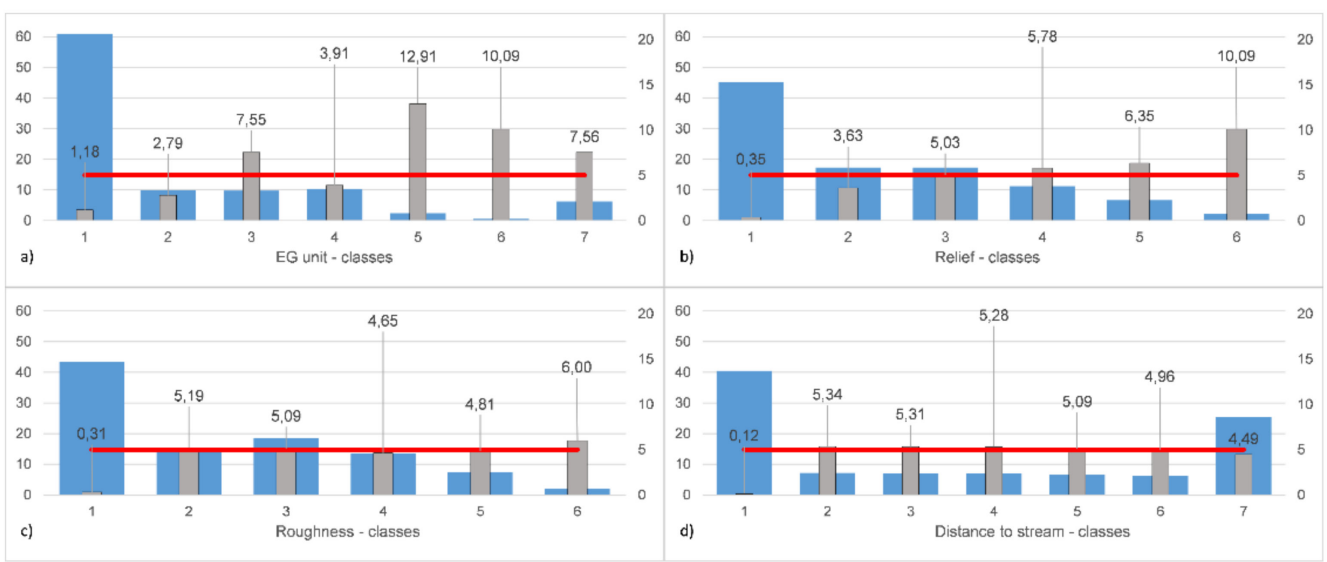

Figure 6. The distribution of predictive factor classes within the study area expressed in percentages (blue columns and left vertical axis) and the percentage of the corresponding class covered with LiDAR polygons (grey columns and right vertical axis), for: (a) EG units, (b) relief, (c) roughness, and (d) distance to streams.

The reliability of the results is also influenced by the accuracy of the data. LiDARbased inventories are precise inventories, considering the HR DTMs used for landslide delineation. Still, visual DTM interpretation involves a certain degree of subjectivity. To maintain the same criteria during the landslide delineation by three different experts and enable the comparability of inventories, the LIC for each landslide is defined. The geological setting for the study area has been defined by available geological maps in a scale of 1:100,000, which is appropriate for regional-scale LSM. Other factor maps were calculated from available DEMs with $20 \mathrm{~m}$ resolution. Therefore, the pixel size of the DEM controls the resolution of the susceptibility estimation, but a resolution of $20 \mathrm{~m}$ is considered to be a suitable resolution for regional-level analysis.

Considering LSM verification, several limitations could also be pointed out. First, landslide locations used for verification, which are digitized from available geological maps, are presented as points. Their spatial accuracy, with respect to the scale of the input maps, can be questionable and can strongly affect verification results, especially when the landslide point is close to the boundary of two different susceptibility zones. Besides limited historical landslide locations, which is almost impossible to present on small-scale maps, weaknesses can be also related to the age of the maps, mapping methodology, georeferencing procedure, and a lack of data in some parts of the study area. Second, not all data collected from the web portal "Report a landslide" can be considered completely accurate until all locations are checked by experts in the field. Nevertheless, most of this data can be considered reliable, as a large number of landslides are reported from the Directorate of Civil Protection, which is involved in most crisis situations related to hazardous events. Some of the landslides related to the latter verification set are located 
within the green zones (low susceptibility) of LSM, which are associated with the banks of the Kupa River. Considering the resolution of input DEMs, it was difficult to highlight the local geomorphological properties within these areas. Thus, these local instabilities have an impact on the verification results. The main constraint arises from limited area and inventory coverage, which is already explained where LiDAR polygons are discussed.

Keeping in mind the limitations caused by showing landslides as points, a part of LiDAR-based inventories with LICs of three or four, as a verification dataset, is also used.

It is also important to point out that the presented LSM is based on landslides, which are mainly initiated by long-lasting/intensive precipitation. Seismic activity and climate change extremes that could initiate landslides in "unusual" locations in the future are not considered here.

\subsection{Purpose and Method of Use}

The LSM does not predict exactly where landslides will occur. Therefore, it is important to emphasize that red zones on the map (zones of very high susceptibility) do not indicate explicitly landslide locations. The susceptibility zones represent areas of different landslide spatial probabilities, i.e., the likelihood of their occurrence due to local terrain conditions [7], neglecting the factor of time.

For the LSM interpretation, it is very important to be aware of the purpose for which the map is made, which greatly influences the corresponding map scale and the methodology used. Besides, the final classification of LSI into susceptibility zones directly influences the final appearance of the map, which is essential for its practical application. For proper LSM use, it is important to prepare a guide for potential end-users, which should contain the description of the methodology used, instructions for map interpretation, and a review of its advantages and limitations. Besides, the LSM presents the summary of the results based on currently available data and the current state of the terrain, which is subject to change over time. Thus, it is recommended that the LSM be updated every few years, incorporating new data, knowledge, and methodologies.

Considering all the limitations presented, the use of the presented 1:100,000 scale LSM is limited to regional-scale studies. The derived LSM could be used for: (i) development of county spatial plans, (ii) identification of landslide problem areas at the regional level, (iii) selection of locations where it is necessary to conduct more detailed EG surveys and create more detailed landslide-susceptibility maps on a local scale (e.g., 1:25,000), (iv) elaboration of disaster risk-management strategy, (v) planning of regional development projects, (vi) setting engineering constraints during the development of large projects, and (vii) informing the local communities and general public.

From all of the above, it can be concluded that the main purpose of the regional-scale LSM is to point out the most susceptible zones in a wider area where detailed research should be conducted and large-scale LSMs produced. In this context, regional LSMs cannot replace detailed engineering geological surveys and should not be used for design purposes. In such a way, the LSM derived for Sisak-Moslavina County can be used to rank the municipalities and cities based on priority for further investigation (Figure 7).

The research results indicate municipalities and cities where $>60 \%$ of the area is determined to be highly susceptible to landsliding. For those, such as Gvozd, Hrvatska Kostajnica, Glina, Dvor, Topusko, and Majur, detailed research should have priority. They should be followed by Donji Kukuruzari and Petrinja, where $>40 \%$ of the area is associated with high susceptibility zones. Among others, within Novska and Kutina, more than ten percent of the area belongs to a very-high susceptibility zone. Jasenovac and Martinska Ves are completely within the zone of least susceptibility, implying the possibility of rare landslide occurrences related to extreme natural events or induced by human interventions. Moreover, within municipalities where low susceptibility zones prevail, such as Sisak and Popovača, detailed investigation should be focused only on local zones determined to be vulnerable. 


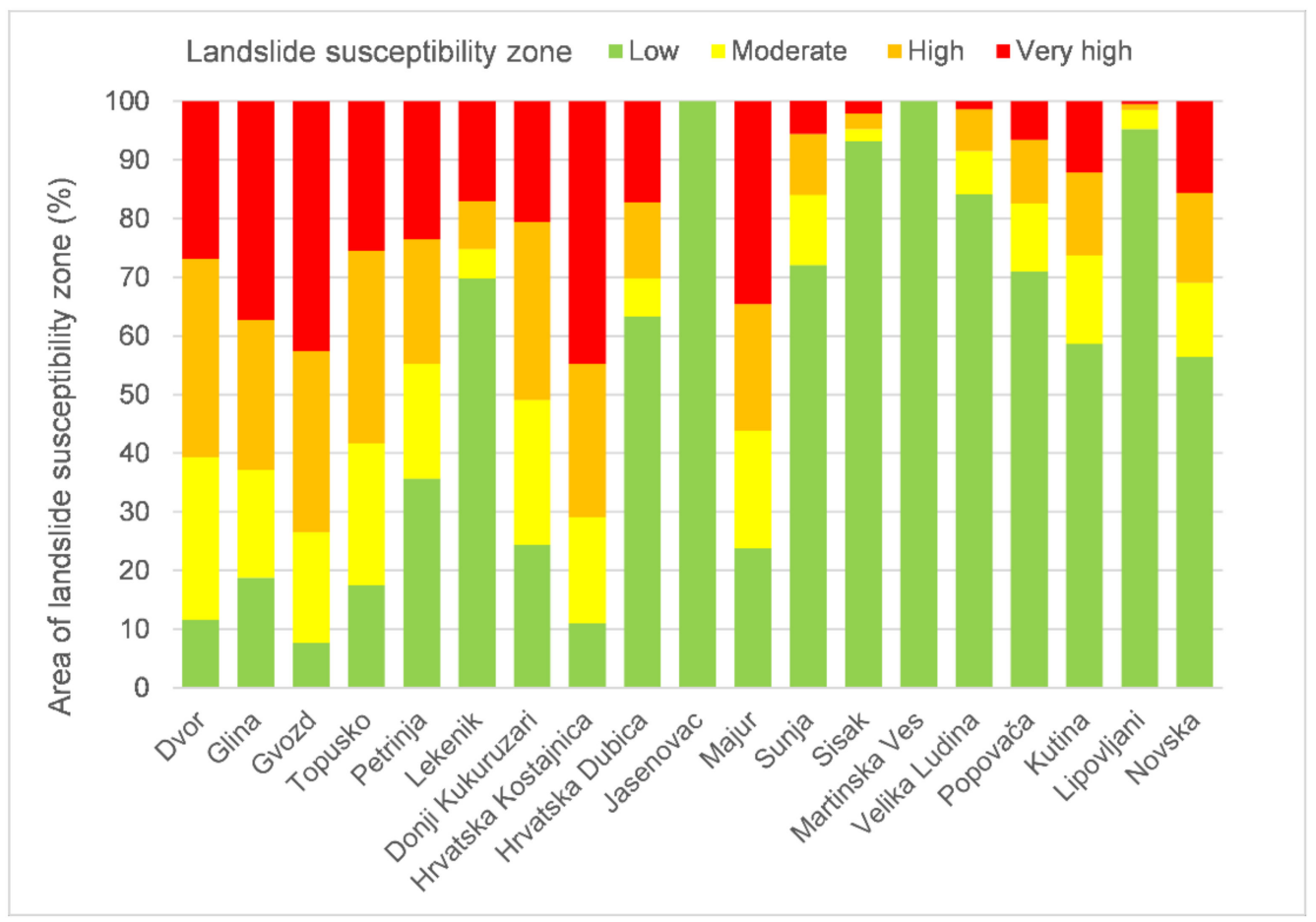

Figure 7. Area distribution of each landslide-susceptibility zone within municipalities and cities in the study area.

\section{Conclusions}

In this paper, a regional-scale 1:100,000 LSM is presented for the $4,466 \mathrm{~km}^{2}$ area of Sisak-Moslavina County in Croatia. To derive the LSM, a statistically based FR method is used for weighting the classes of each predictive factor, and the results were integrated using the AHP method to classify the importance of each factor in landslide-susceptibility mapping. The results of this approach are presented by the spatial distribution of LSI, whose values range from 0 to 47 . After LSI reclassification, the terrain was divided into four landslide-susceptibility zones: low, moderate, high, and very high, covering $50 \%, 14 \%$, $17 \%$, and $19 \%$ of the area, respectively.

The most important concern that defined the goal of this paper was whether the use of a limited amount of LiDAR data over such a large area would yield a sufficiently good and usable landslide-susceptibility map. Based on the verification results, it can be concluded that the approach presented in this paper is encouraging for primary regional-level studies, justifying the cost-benefit ratio.

However, it should be emphasized that such a limited amount of key and expensive data in the process of LSM production, i.e., LiDAR data, would not be convenient enough if the analysis of the EG units and environmental parameters were not performed before the definition of LiDAR polygon positioning. Such an approach resulted in a statistically balanced landslide inventory sample and is certainly recommended for similar research in the future.

The results achieved in the form of an LSM at a scale of 1:100,000 can be used for different purposes on a regional and local level, with awareness of its advantages and limitations emphasized in the paper. The regional-scale LSM is a good reference point to detect areas for which detailed research is necessary. The more detailed the research is, the more expansive investigation will be. Thus, for the most financially demanding phase, the main objective is to reduce the investigation area and to direct resources and detailed research to the most vulnerable sites in the region.

As part of a comprehensive landslide risk-management system, the development of LSMs is the basis for further hazard and risk assessment. Therefore, the systematic 
monitoring of landslide occurrences and the damage they cause is crucial and is possible only with the cooperation of engineering geologists, local communities, and civil protection.

Author Contributions: All authors conceptualized the main research purpose of the paper. I.B. and M.F. performed the analysis, prepared the data, tables, and figures, and wrote the majority of the first draft of the paper. V.G. and D.P. contributed with paper review and editing. All authors have read and agreed to the published version of the manuscript.

Funding: LiDAR data used in this study were acquired through the framework of the safEarth project, implemented under the Interreg IPA Cross-border Cooperation Program Croatia-Bosnia and Herzegovina-Montenegro 2014-2020, under Project ID HR-BA-ME59.

Institutional Review Board Statement: Not applicable.

Informed Consent Statement: Not applicable.

Data Availability Statement: Not applicable.

Acknowledgments: The authors kindly thank the following colleagues from the Croatian geological survey: Tihomir Frangen for preparing the LiDAR-based landslide inventory for the area of Petrinja and Josip Kolarić, GE, and Ivan Markotić, mag. geol., for digitizing the landslides from available geological maps.

Conflicts of Interest: The authors declare no conflict of interest.

\section{References}

1. Schuster, R.L. Socioeconomic Significance of Landslides. In Landslides-Investigation and Mitigation; Turner, A.K., Schuster, R.L., Eds.; Transportation Research Board Special Report; National Academy Press: Washington, DC, USA, 1996; Volume 247, pp. 12-35.

2. Crozier, M.J. Deciphering the Effect of Climate Change on Landslide Activity: A Review. Geomorphology 2010, 124, 260-267. [CrossRef]

3. Gariano, S.L.; Guzzetti, F. Landslides in a Changing Climate. Earth-Sci. Rev. 2016, 162, 227-252. [CrossRef]

4. Bell, F.G. Geological Hazards: Their Assessment, Avoidance and Mitigation; Taylor \& Francis e-Library: London, UK, 2002.

5. Hervas, J.; Bobrowsky, P.T. Mapping: Inventories, Susceptibility, Hazard and Risk. In Landslides-Disaster Risk Reduction; Sassa, K., Canuti, P., Eds.; Springer: Berlin, Germany, 2009; pp. 321-349. [CrossRef]

6. Corominas, J.; Van Westen, C.; Frattini, P.; Cascini, L.; Malet, J.-P.; Fotopoulou, S.; Catani, F.; Van Den Eeckhaut, M.; Mavrouli, O.; Agliardi, F.; et al. Recommendations for the Quantitative Analysis of Landslide Risk. Bull. Eng. Geol. Environ. 2014, 73, 209-263. [CrossRef]

7. Brabb, E.E. Innovative approaches to landslide hazard and risk mapping. In Proceedings of the 4th International Symposium on Landslides, Toronto, ON, USA, 16-21 September 1984; Canadian Geotechnical Society: Toronto, ON, Canada, 1984; Volume 1, pp. 307-324.

8. Chacón, J.; Irigaray, C.; Fernández, T.; El Hamdouni, R. Engineering Geology Maps: Landslides and Geographical Information Systems. Bull. Eng. Geol. Environ. 2006, 65, 341-411. [CrossRef]

9. Fell, R.; Corominas, J.; Bonnard, C.; Cascini, L.; Leroi, E.; Savage, W.Z. Guidelines for Landslide Susceptibility, Hazard and Risk Zoning for Land Use Planning. Eng. Geol. 2008, 102, 85-98. [CrossRef]

10. Cascini, L. Applicability of Landslide Susceptibility and Hazard Zoning at Different Scales. Eng. Geol. 2008, 102, 164-177. [CrossRef]

11. Van Westen, C.J.; Rengers, N.; Terlien, M.T.J.; Soeters, R. Prediction of the occurrence of slope instability phenomena through GIS-based hazard zonation. Geol. Rundsh. 1997, 86, 404-414. [CrossRef]

12. Reichenbach, P.; Rossi, M.; Malamud, B.D.; Mihir, M.; Guzzetti, F. A Review of Statistically-Based Landslide Susceptibility Models. Earth-Sci. Rev. 2018, 180, 60-91. [CrossRef]

13. Schicker, R.; Moon, V. Comparison of Bivariate and Multivariate Statistical Approaches in Landslide Susceptibility Mapping at a Regional Scale. Geomorphology 2012, 161-162, 40-57. [CrossRef]

14. Manzo, G.; Tofani, V.; Segoni, S.; Battistini, A.; Catani, F. GIS Techniques for Regional-Scale Landslide Susceptibility Assessment: The Sicily (Italy) Case Study. Int. J. Geogr. Inf. Sci. 2013, 27, 1433-1452. [CrossRef]

15. Ahmed, M.F.; Rogers, J.D.; Ismail, E.H. A Regional Level Preliminary Landslide Susceptibility Study of the Upper Indus River Basin. Eur. J. Remote Sens. 2014, 47, 343-373. [CrossRef]

16. Chalkias, C.; Polykretis, C.; Ferentinou, M.; Karymbalis, E. Integrating Expert Knowledge with Statistical Analysis for Landslide Susceptibility Assessment at Regional Scale. Geosciences 2016, 6, 14. [CrossRef]

17. Hung, L.Q.; Van, N.T.H.; Duc, D.M.; Ha, L.T.C.; Van Son, P.; Khanh, N.H.; Binh, L.T. Landslide Susceptibility Mapping by Combining the Analytical Hierarchy Process and Weighted Linear Combination Methods: A Case Study in the Upper Lo River Catchment (Vietnam). Landslides 2016, 13, 1285-1301. [CrossRef] 
18. Zhou, S.; Chen, G.; Fang, L.; Nie, Y. GIS-Based Integration of Subjective and Objective Weighting Methods for Regional Landslides Susceptibility Mapping. Sustainability 2016, 8, 334. [CrossRef]

19. Du, G.L.; Zhang, Y.S.; Iqbal, J.; Yang, Z.H.; Yao, X. Landslide Susceptibility Mapping Using an Integrated Model of Information Value Method and Logistic Regression in the Bailongjiang Watershed, Gansu Province, China. J. Mt. Sci. 2017, 14, 249-268. [CrossRef]

20. Milevski, I.; Dragićević, S.; Zorn, M. Statistical and Expert-Based Landslide Susceptibility Modeling on a National Scale Applied to North Macedonia. Open Geosci. 2019, 11, 750-764. [CrossRef]

21. Rabby, Y.W.; Li, Y. Landslide Susceptibility Mapping Using Integrated Methods: A Case Study in the Chittagong Hilly Areas, Bangladesh. Geosciences 2020, 10, 483. [CrossRef]

22. Guzzetti, F.; Mondini, A.C.; Cardinali, M.; Fiorucci, F.; Santangelo, M.; Chang, K.-T. Landslide Inventory Maps: New Tools for an Old Problem. Earth-Sci. Rev. 2012, 112, 42-66. [CrossRef]

23. Bognar, A. Geomorfološka regionalizacija Hrvatske [The Geomorphological Regionalization of Croatia-In Croatian]. Acta Geogr. Croat. 2001, 34, 7-29.

24. Husnjak, S.; Bogunović, M.; Jurišić, M. Geoinformatička obrada pedoloških podataka za uzgoj povrća na području SisačkoMoslavačke županije [Geoinformatic Processing of Pedological Data for Vegetable Farming in the Sisak-Moslavina County-In Croatian]. Agron. Glas. 2000, 227-246.

25. Sisačko-Moslavačka Županija. Izvješće o Stanju u Prostoru Sisačko-Moslavačke Županije 2015-2018; Report on the Spatial Situation in the Sisak-Moslavina County-In Croatian. Zavod za Prostorno Uređenje Sisačko-Moslavačke Županije: Sisak, Croatia, 2019; 65p.

26. Bogunović, M.; Vidaček, Ž.; Racz, Z.; Husnjak, S.; Sraka, M. Namjenska pedološka karta Republike Hrvatske i njena uporaba [The Practical Aspects of Soil Suitability Map of Croatia-In Croatian]. Agron. Glas. 1997, 59, 363-399.

27. Hećimović, I.; Avanić, R. Geološka Karta Sisačko-Moslavačke Županije [Geological Map of Sisak-Moslavina County—In Croatian]; Prilog br. 1 iz Rudarsko-geološke studije Sisačko-moslavačke županije [Annex No. 1 from Mining and Geological Study of Sisak-Moslavina County-In Croatian]; Croatian Geological Survey: Zagreb, Croatia, 2014.

28. Kruk, B.; Dedić, Ž.; Avanić, R.; Peh, Z.; Kruk, L.; Kovačević Galović, E.; Kolbah, S.; Škrlec, M.; Crnogaj, S. Rudarsko-Geološka Studija Sisačko-Moslavačke Županije [Mining and Geological Study of Sisak-Moslavina County-In Croatian]; Department of Mineral Resources, Croatian Geological Survey: Zagreb, Croatia, 2016.

29. Šikić, K. Tumač Osnovne Geološke Karte RH za List Bosanski Novi 1:100,000, L 33-105 [The Guidelines of the Basic Geological Map of the Republic of Croatia for the Sheet Bosanski Novi 1: 100,000 - In Croatian]; Croatian Geological Survey: Zagreb, Croatia, 2014.

30. Jelaska, V.; Bulić, J.; Oreški, E. Stratigrafski Model Eocenskog Fliša Banije [The Stratigraphic Model of the Eocene Flysch of Banija-In Croatian]. Geološki Vjesnik 1970, 23, 81-94.

31. Avanić, R. Litostratigrafske Jedinice Donjeg Miocena Sjeverozapadne Hrvatske [The Lithostratigraphic Units of the Early Miocene of Northwestern Croatia-In Croatian]. Ph.D. Thesis, Faculty of Science, University of Zagreb, Zagreb, Croatia, 2012.

32. Avanić, R.; Kovačić, M.; Pavelić, D.; Miknić, M.; Vrsaljko, D.; Bakrač, K.; Galović, I. The Middle and Upper Miocene Facies of Mt. Medvednica (Northern Croatia). In Proceedings of the 22nd IAS Meeting of Sedimentology; Field Trip Guidebook; Vlahović, I., Tišljar, J., Eds.; Croatian Geological Survey: Zagreb, Croatia, 2003; pp. 167-172.

33. Avanić, R.; Šimunić, A.; Peh, Z. Geology of the Croatian Zagorje Region. In Proceedings of the 5th Slovenian Geological Congress; Post congress field trip book; Rman, N., Marković, T., Brenčić, M., Eds.; Geological Survey of Slovenia: Ljubljana, Slovenia, $2018 ;$ p. 35.

34. Kovačić, M. Sedimentologija Gornjomiocenskih Naslaga Jugozapadnog Dijela Panonskog Bazena [Sedimentology of the Upper Miocene Deposits from the Southwest Part of the Pannonian Basin-In Croatian]. Ph.D. Thesis, Faculty of Science, University of Zagreb, Zagreb, Croatia, 2004.

35. Grizelj, A. Mineraloške i Geokemijske Značajke Gornjomiocenskih Pelitnih Sedimenata Jugozapadnog Dijela Hrvatskog Zagorja [Mineralogical and Geochemical Characteristics of Upper Miocene Pelitic Sediments of the South-Western Part of Hrvatsko Zagorje-In Croatian]. Master's Thesis, Faculty of Science, University of Zagreb, Zagreb, Croatia, 2004.

36. Avanić, R.; Kovačić, M.; Pavelić, D.; Peh, Z. The Neogene of Hrvatsko Zagorje. In Proceedings of the 9th Mid-European Clay Conference; Conference book, Field Trip Guide book; Tibljaš, D., Horvat, M., Tomašić, N., Mileusnić, M., Grizelj, A., Eds.; Croatian Geological Society, Croatian Geological Survey, Faculty of Mining, Geology and Petroleum Engineering, and Faculty of Science-University of Zagreb: Zagreb, Croatia, 2018; pp. 128-129.

37. Pikija, M. Tumač Osnovne Geološke Karte SFRJ za List Sisak 1:100,000 L 33-93 [The Guidelines of the Basic Geological Map of the Republic of Croatia for the Sheet Sisak 1:100,000 - In Croatian]; Institut za Geološka Istraživanja, Zagreb, Savezni Geol. Zavod: Beograd, Serbia, 1986.

38. Halamić, J.; Belak, M.; Pavelić, D.; Avanić, R.; Šparica, M.; Brkić, M.; Kovačić, M.; Vrsaljko, D.; Banak, A.; Crnko, J. Osnovna Geološka Karta Republike Hrvatske 1:50,000—Požeška Gora [Basic Geological Map of the Republic of Croatia 1:50,000—Požě̌ka Gora-In Croatian]; Croatian Geological Survey: Zagreb, Croatia, 2019.

39. Varnes, D.J.; IAEG. Landslide Hazard Zonation: A Review of Principles and Practice; UNESCO: Paris, France, 1984.

40. Van Westen, C.J. The Modeling of Landslide Hazards Using GIS. Surv. Geophys. 2000, 21, 241-255. [CrossRef]

41. Althuwaynee, O.F.; Pradhan, B.; Park, H.J.; Lee, J.H. A Novel Ensemble Bivariate Statistical Evidential Belief Function with Knowledge-Based Analytical Hierarchy Process and Multivariate Statistical Logistic Regression for Landslide Susceptibility Mapping. Catena 2014, 114, 21-36. [CrossRef] 
42. Čubrilović, P.; Palavestrić, L.; Nikolić, T.; Ćirić, B. Inženjerskogeološka Karta SFR Jugoslavije u Mjerilu 1:500,000 [Engineering Geological Map of SFR of Yugoslavia at a Scale of 1:500,000_In Croatian]; Savezni Geološki Zavod: Beograd, Serbia, 1967.

43. Crnko, J. Osnovna Geološka Karta Republike Hrvatske 1:100,000, List Kutina [Basic Geological Map of Republic of Croatia, 1:100,000. Kutina Sheet-In Croatian]; Croatian Geological Survey: Zagreb, Croatia, 2014.

44. Ardizzone, F.; Cardinali, M.; Galli, M.; Guzzetti, F.; Reichenbach, P. Identification and Mapping of Recent Rainfall-Induced Landslides Using Elevation Data Collected by Airborne Lidar. Nat. Hazards Earth Syst. Sci. 2007, 7, 637-650. [CrossRef]

45. Van Den Eeckhaut, M.; Poesen, J.; Verstraeten, G.; Vanacker, V.; Nyssen, J.; Moeyersons, J.; Van Beek, L.P.H.; Vandekerckhove, L. Use of LIDAR-Derived Images for Mapping Old Landslides under Forest. Earth Surf. Process. Landforms 2007, 32, 754-769. [CrossRef]

46. Jaboyedoff, M.; Oppikofer, T.; Abellán, A.; Derron, M.-H.; Loye, A.; Metzger, R.; Pedrazzini, A. Use of LIDAR in Landslide Investigations: A Review. Nat. Hazards 2012, 61, 5-28. [CrossRef]

47. McCalpin, J. Preliminary Age Classification of Landslides for Inventory Mapping. In Proceedings 21st Annual Enginnering Geology and Soils Engineering Symposium; University Press: Moscow, Russia, 1984; pp. 99-111.

48. Keaton, J.R.; Degraff, J.V. Surface Observation and Geologic Mapping. In Landslides_Investigation and Mitigation; Turner, A.K., Schuster, R.L., Eds.; Transportation Research Board Special Report; National Academy Press: Washington, DC, USA, 1996; Volume 247, pp. 178-230.

49. Allaby, A.; Allaby, M. A Dictionary of Earth Sciences, 2nd ed.; Oxford University Press: Oxford, UK, 2003.

50. Pradhan, A.M.S.; Kim, Y.T. Rainfall-Induced Shallow Landslide Susceptibility Mapping at Two Adjacent Catchments Using Advanced Machine Learning Algorithms. ISPRS Int. J. Geo-Inf. 2020, 9, 569. [CrossRef]

51. Foumelis, M.; Lekkas, E.; Parcharidis, I. Landslide Susceptibility Mapping By Gis-Based Qualitative Weighting Procedure in Corinth Area. Bull. Geol. Soc. Greece 2018, 36, 904. [CrossRef]

52. Berti, M.; Corsini, A.; Daehne, A. Comparative Analysis of Surface Roughness Algorithms for the Identification of Active Landslides. Geomorphology 2013, 182, 1-18. [CrossRef]

53. Grohmann, C.H.; Smith, M.J.; Riccomini, C. Multiscale Analysis of Topographic Surface Roughness in the Midland Valley, Scotland. IEEE Trans. Geosci. Remote Sens. 2011, 49, 1200-1213. [CrossRef]

54. Gökceoglu, C.; Aksoy, H. Landslide Susceptibility Mapping of the Slopes in the Residual Soils of the Mengen Region (Turkey) by Deterministic Stability Analyses and Image Processing Techniques. Eng. Geol. 1996, 44, 147-161. [CrossRef]

55. Prabhakaran, A.; Jawahar Raj, N. Drainage Morphometric Analysis for Assessing Form and Processes of the Watersheds of Pachamalai Hills and Its Adjoinings, Central Tamil Nadu, India. Appl. Water Sci. 2018, 8, 1-19. [CrossRef]

56. Lee, S.; Talib, J.A. Probabilistic Landslide Susceptibility and Factor Effect Analysis. Environ. Geol. 2005, 47, 982-990. [CrossRef]

57. Saaty, R.W. The Analytic Hierarchy Process-What It Is and How It Is Used. Math. Model. 1987, 9, 161-176. [CrossRef]

58. Ghosh, S.; Carranza, E.J.M.; van Westen, C.J.; Jetten, V.G.; Bhattacharya, D.N. Selecting and Weighting Spatial Predictors for Empirical Modeling of Landslide Susceptibility in the Darjeeling Himalayas (India). Geomorphology 2011, 131, 35-56. [CrossRef]

59. Tobler, W. Measuring Spatial Resolution. In Proceedings of the Land Resources Information Systems Conference, Beijing, China, 25-29 October 1987; pp. 12-16.

60. Mahalingam, R.; Olsen, M.J.; O’Banion, M.S. Evaluation of Landslide Susceptibility Mapping Techniques Using Lidar-Derived Conditioning Factors (Oregon Case Study). Geomat. Nat. Hazards Risk 2016, 7, 1884-1907. [CrossRef]

61. Rossi, M.; Guzzetti, F.; Reichenbach, P.; Mondini, A.C.; Peruccacci, S. Optimal Landslide Susceptibility Zonation Based on Multiple Forecasts. Geomorphology 2010, 114, 129-142. [CrossRef] 